\title{
ADMINISTRATION AND MANAGEMENT OF IRRIGATION WATER IN 24 USER ORGANIZATIONS IN CHILE
}

\author{
Jorge Jara ${ }^{*}$, Marco A. López ${ }^{1}$, Álvaro San Martín², Luis Salgado ${ }^{\text {, and Ovidio Melo }}{ }^{1}$
}

\begin{abstract}
Approximately $85 \%$ of the water consumed in Chile is destined to agricultural irrigation and is managed by the users themselves. This study analyzed the price that irrigation water users pay to their Water User Associations (WUAs) to which they belong and the relationship of this price to the professional level and performance of the WUAs. The study included 24 WUAs: 10 River Administration Boards (JV) and 14 Irrigation Canal Associations (AC). The annual operational budget of each WUA, the price paid by users and the management capacities of the board of directors of each WUA were compared. The study also determined the relative value of user payments to WUAs as a proportion of total production costs of the main crops in each zone. The variability of user fees per irrigated hectare decreases when the irrigation area of the WUA is more than 10000 ha, though this was not observed in JVs. The presence of technical-professional staff directly affects the development and growth of the WUAs. As well, the WUAs with a greater level of capacity development (NDC) have more board members with a higher education level and have lower rates of unpaid user fees. The price that users pay to the WUA by irrigated hectare represents less than $4.0 \%$ of the average total production cost of the main crops in the study area. Finally, no correlation was found between the prices that users pay and the average profitability of the main crops, or between price and the geographical location of the WUAs.
\end{abstract}

Key words: water cost, water users associations, WUAs, water canal associations, river administration board.

\section{INTRODUCTION}

In different countries in Latin America and the Caribbean there are efforts to encourage changes in legislation and organizations related to the management and use of water for irrigation. These reforms vary from one country to another in terms of their execution, progress and content (Garduño, 2003, Huamanchumo et al., 2008). Brazil, Chile, Colombia, Jamaica and Mexico have reformed the institutional character of water management, while the majority of other countries are in the process of making legal and institutional changes (Jouravlev, 2001).

Approximately 85\% of water consumed in Chile is used in agricultural irrigation (Ministry of Public Work-General Water Directorate, 1999), a resource that is administered by the users themselves through organizations recognized

${ }^{1}$ Universidad de Concepción, Facultad de Ingeniería Agrícola, Casilla 537, Chillán, Chile. *Corresponding author (jcjara@udec.cl).

${ }^{2}$ Dirección General de Aguas, Unidad de Administración de Recursos Hídricos, Caupolicán s/n Edificios Públicos $3^{\text {er }}$ piso Of. 7, Los Ángeles, Chile (alvaro.sanmartin.s@mop.gov.cl).

Received: 16 May 2008.

Accepted: 20 August 2008. by law and with their own regulations and autonomous boards of directors.

The costs assumed by users for irrigation water services in the majority of Latin American countries have not been analyzed in-depth. In fact, some works have been carried out in recent years related to valuing irrigation water that tangentially address the cost of the service. Notably, there are works to estimate the economic and/or environmental value of irrigation water by Dinar (2000) cited by Çakmak et al. (2004), Herrera et al. (2004), Garrido et al. (2007) and Huamanchumo et al. (2008).

Water resources in Chile are the responsibility of the General Water Directorate, a body under the Ministry of Public Works, which grants water use rights without cost for the user. Nevertheless, the catchment, conduction and distribution of water resources, which imply administrative and operational costs, are the responsibility of Water User Associations (WUAs). These are regulated by the Water Code and have the objective of administering water sources and works through which water resources are extracted, captured and/or conducted and distributed among users. As well, they are responsible for resolving conflicts among such users (Galaz, 2004).

The Water Code (Republic of Chile, 2006) defines three types of organizations: (1) River Administration 
Boards (JV), (2) Irrigation Canal Associations (AC) and (3) Water Communities. JVs are constituted on the basis of natural water sources, including ground water. ACs are constituted on the basis of artificial water sources, normally canal networks of multi-farm irrigation systems. Water Communities are constituted on the basis of artificial water sources and distribute water according to the user rights of their members.

According to the CPA-SIGIRH-V8.03 Information System of the Public Water Registry of the General Water Directorate, there are currently $39 \mathrm{JVs}$ and 168 ACs registered, which in general have professionalized their administration and comply with the functions they are charged with under existing legislation. At the same time, there are 3218 water communities registered at the national level, the majority of which are weak in technical, legal, administrative, financial and operational aspects, and with low levels of management and serious problems in intake, conduction and distribution of water resources. They have not developed institutional networks and are characterized by high levels of conflict (Melo et al., 2005). As well, there are a number of additional organizations, especially among water communities, which operate informally and do not fully exercise their legal rights (Galaz, 2004).

There are WUAs in Chile that administer water for large areas under irrigation (> $30000 \mathrm{ha}$ ) without having permanent engineers or technical staff, and at the same time there are others smaller WUAs with one or more professional staff, without a clear or direct relationship between the fees user have to pay to their organization (Melo et al., 2005). The success of the latter has been based mainly on the capacity to professionalize the administration of the organization. As well, the support team (engineers, lawyers, technicians and accountants) carries out activities on behalf of the organization's board of directors, such as improving the quality of the service, earning extra incomes and implementing systems of gradual penalties to reduce the rate of unpaid user fees and other practices against the interests of the users.

Given this, it is estimated that a small WUA, without professional support would have difficulty in meeting all its obligations. This suggests that there is a minimum irrigation surface area under the responsibility of a WUA that makes it economically viable for the WUA to professionalize itself, taking into consideration agroclimatic and sociocultural factors.

The objective of this work was to analyze the cost that users should pay based on administration, operation and management in 24 WUAs and the relationship to the level of professionalization, management capacity and performance of these organizations and their impact on production costs.

\section{MATERIALS AND METHODS}

Twenty-four WUAs (JV and AC) from the Coquimbo to the Bio-Bio Regions were studied. The WUAs studied were willing to share their financial records, budget for the irrigation season of 2005-2006 and information about the total surface area under irrigation that they administer, as well as geographic maps and information about the administrative characteristics of the organization. The initial stage of the study was interviews with representatives of each organization (members of boards of directors, managers or administrators) with the objective of obtaining primary information. As well, a semi-structured interview was applied to the members of the boards of directors with the objective of relating their characteristics of age, years in the position, participation, contact with other organizations and educational level, among others, that can influence the functioning of the WUA. Finally, secondary information was evaluated to determine if there was a correlation between the profitability of the crops that predominate in the areas of jurisdiction of these organizations and the price that users pay for the administration of the irrigation system. The research stage and information gathering was carried out from April to June of 2006.

The level of prices and costs presented by the WUAs were evaluated, for the period of May 2005 to April 2006. The exchange rate used of $\$ 541.7$ Chilean pesos per US dollar was estimated based on data published by the Central Bank of Chile (2008), considering the average rate of exchange for the period indicated, which presented a standard deviation of $\$ 24.2$ pesos.

\section{Primary information}

This refers to the economic resources used during the irrigation season of 2005-2006 in each of the organizations evaluated, identifying or recovering administrative and operational costs, highlighting among others the operation of irrigation intakes structures, cleaning canals and professional or administrative fees. As well, this includes information related to technical and administrative aspects of the organization such as the total area under irrigation, the number of water right allotments under the jurisdiction and water resources that are managed.

The information related to the leadership capacity and performance of the board of directors of each organization was gathered by means of semi-structured interviews conducted with members of 19 of the 24 boards of the WUAs that agreed to participate in this part of the study.

\section{Secondary information}

This refers to bibliographic information available on the surface area destined to the main crops in the areas of the study (Larrañaga et al., 2003; 2004; 2005; 2006), their 
proportional participation in each WUA and information about the total production costs and average gross margin (Fundación Chile, 2007).

\section{Characterization of the WUAs}

To characterize the WUA an instrument termed the Capacities Development Level (NDC) was used. It was designed by the National Irrigation Commission in collaboration with the Universidad de Concepción (de Miguel, 2005). It allows for classifying, characterizing and typifying the WUAs into seven categories according to the development of their management and administrative capacities, legal situation, participation of users and other organizational aspects (Table 1). Field trips were made to each WUA and members of the boards of directors, technical staff and users were interviewed and selfevaluation test (San Martín, 2007) was applied.

\section{Calculating the annual budget}

Subsequent to the information gathering stage, a study was prepared on the operational expenses of WUAs, the resources used and administrative costs, including among others, security personnel, accountant and clerical staff, as well as the fees of professionals who render managerialadministrative and legal-technical services, infrastructural and operational expenses to maintain the functioning of the system such as upkeep of inlets and cleaning. The gathering and analysis of these data allowed for estimating the annual budget necessary for the functioning of the WUAs according to:

\section{Annual budget $=$ Administration costs + Operational costs + Investments}

Administrative expenses include salaries (administrator, engineer, accountant, secretary, guard, benefits, bonuses, insurance and others), fees (engineer, lawyer, accountant and that are not core staff), office rental, office materials and basic services (telephone, fax, internet, electricity, water, radio), vehicle or transportation (fuel and maintenance). Operational expenses refer to the opening and closing of inlets structures, support to the JV if it corresponds, cleaning of canals, maintenance, security staffs, machine rental, trucking and transport. Investments include construction, repairs and repositioning of works and contingencies.

The total amount collected (MTR) annually by the WUA is:

$$
\text { MTR }=\text { MRC }+ \text { Grants }+ \text { Others }
$$

where MRC is the amount collected through user fees of the organization in a season ( $\$$ season $^{-1}$ ), Grants refers to the amount obtained ( $\$$ season $^{-1}$ ) through projects presented under Law $\mathrm{N}^{\circ} 18450$ for the promotion of private investment in irrigation and drainage works, and Other considers judicial fees and extraordinary improvement programs.

\section{Determination of cost per hectare}

With the amount collected by the users fees charged to users of the system (MRC) and the total area under irrigation administered by the WUA (SBR), the price paid by user to irrigate one hectare of land $(P P U)$, is expressed as:

$$
P P U=\frac{M R C}{S B R}\left(\$ \text { ha }^{-1} \text { season }^{-1}\right)
$$

The choice of $P P U$ instead of the price for nominal flow (water right allocated as a part of the canal flow) that the user pay is due to the lack of correspondence observed between the values of the water right allotments and the water discharges that they represent, which is characteristic of and unique to each WUA (Table 2). As well, reliable water measurements are not always available throughout the irrigation seasons for all the participating WUAs, which would allow for obtaining an average seasonal water flow or fair estimation of the volume of water that corresponds to a water right allotment. Nevertheless, all the organizations have reliable and detailed information about the irrigation area under their jurisdiction, because of which, for comparative purposes, the PPU is adequate.

\section{Production costs, average gross margin and price paid by users}

To obtain the proportion of the cost of the administration cost of the water in the total cost of the main crops in territories of the respective WUAs, databases were reviewed with information on the main crops, based on the fruit registry of the ODEPA-CIREN (Larrañaga et al., 2003; 2004; 2005; 2006). Likewise, the weighted profitability of the areas under irrigation was estimated using information on production costs, gross incomes, profitability or average gross margin (Fundación Chile, 2007), and it was determined whether there was a correlation between this parameter and the value paid by users for the administration of water resources in their system.

\section{RESULTS AND DISCUSSION}

\section{Characterization of the WUAs}

Of the 24 WUAs considered, 10 were JVs and 14 ACs (Table 2). Thus, of the total of $39 \mathrm{JVs}$ and 168 ACs registered at the national level, $25.6 \%$ of the JVs and $8.3 \%$ of the ACs were included in the study. The total study represented $11.6 \%$ of the total of JVs and ACs registered in the country. Each WUA manages an irrigation system that covers more than 2500 ha, the largest being the Maule 
Table 1. Level of Capacity Development (NDC) of the Water User Associations (WUAs).

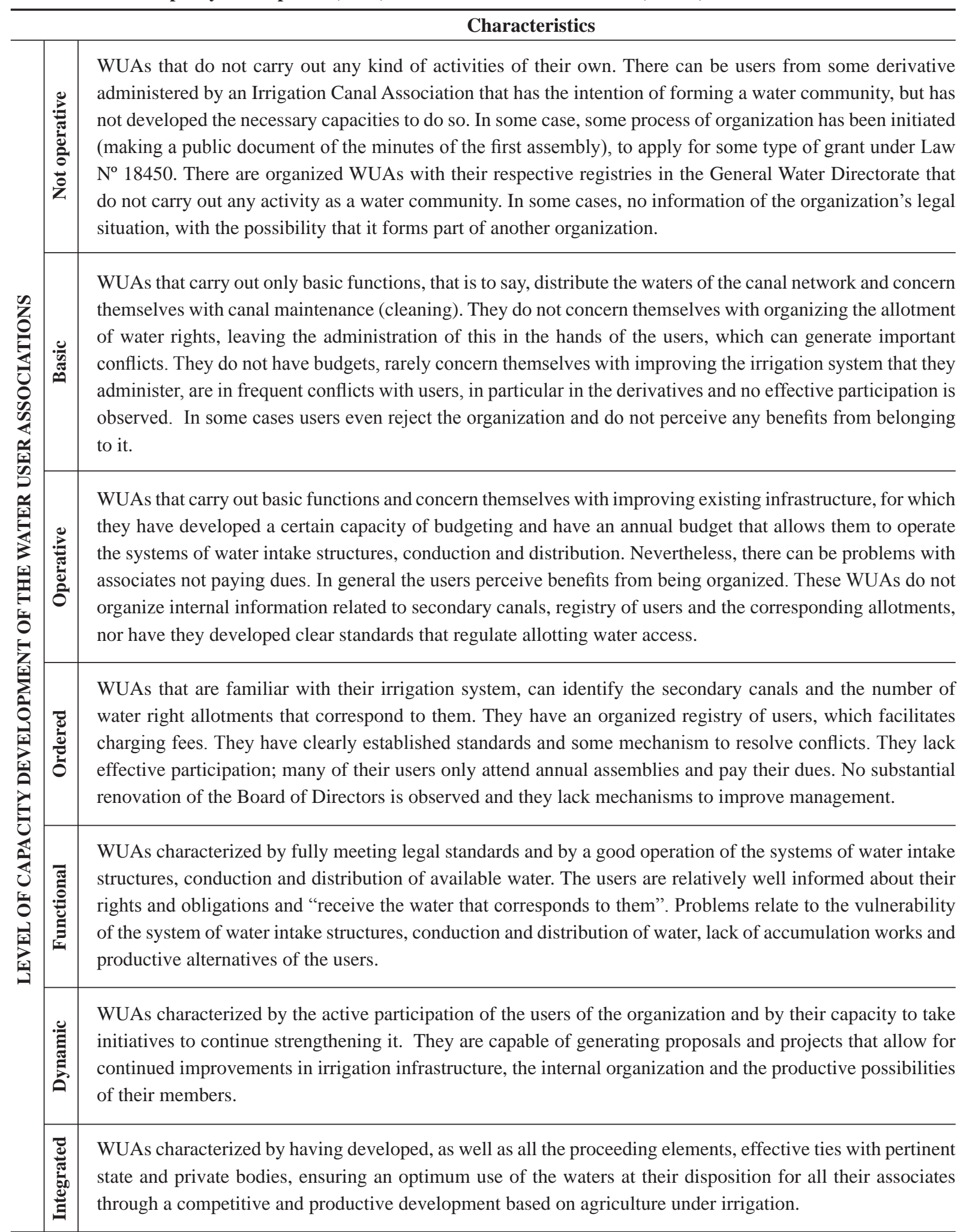

Source: Final Report “Development of a Methodology of Organization and Training for Water Communities”. Agreement between the National Irrigation Commission and the Universidad de Concepción, Faculty of Agricultural Engineering, January 2003 (de Miguel, 2005). 
Table 2. Nominal discharge managed $(\mathrm{Qn})$, nominal discharge per water right allotment $\left(\mathrm{Q}_{\mathrm{Acc}}\right)$ and area under irrigation (SBR) in 25 Water User Associations (WUAs) surveyed.

\begin{tabular}{|c|c|c|c|c|}
\hline Region & Name of the WUA & $Q_{n}\left(m^{3} s^{-1}\right)$ & $\mathbf{Q}_{\text {Acc }}\left(\mathbf{L ~ s}^{-1} \mathbf{a c c}^{-1}\right)$ & SBR (Mha) \\
\hline \multirow{6}{*}{ 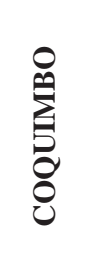 } & AC Punitaqui Canal & 0.82 & 1.0 & 2.7 \\
\hline & JV Illapel River & 0.40 & 1.0 & 3.5 \\
\hline & JV Combarbalá River & 3.61 & 1.0 & 2.5 \\
\hline & JV Choapa River & 18.26 & 1.0 & 10.7 \\
\hline & JV Limarí and Grande Rivers and streams & 24.59 & 1.0 & 20.5 \\
\hline & JV Elqui River & 25.34 & 1.0 & 23.5 \\
\hline $\mathbf{R M}$ & AC del Maipo & 19.96 & 15.0 & 30.0 \\
\hline \multirow{3}{*}{ 吊 } & JV Cachapoal River $1^{\text {a }}$ Section & - & - & 48.0 \\
\hline & AC San Pedro Población y Derivados Canal & 7.36 & 2.7 & 2.7 \\
\hline & AC Cachapoal Canal & 3.68 & 14.1 & 5.0 \\
\hline \multirow{6}{*}{ 恐 } & JV Achibueno River & 19.96 & 1.5 & 12.0 \\
\hline & AC Putagán Canal & 4.29 & 1.0 & 20.0 \\
\hline & AC Maule Norte Canal & 51.78 & 15.0 & 70.0 \\
\hline & AC Maule Sur & 34.40 & 1.4 & 25.0 \\
\hline & JV Ancoa River and streams & 7.42 & 1.0 & 9.0 \\
\hline & JV Maule River & 199.98 & 1.4 & 180.6 \\
\hline \multirow{8}{*}{ 을 } & AC del Laja & 68.49 & 15.0 & 55.0 \\
\hline & AC Zañartu Canal & 29.18 & 10.0 & 40.0 \\
\hline & JV Diguillín River and streams & 33.39 & 15.1 & 33.0 \\
\hline & AC Bío-Bío Norte Canal & 10.70 & 15.0 & 10.0 \\
\hline & AC Bío-Bío Negrete Canal & 17.98 & 15.9 & 8.0 \\
\hline & Coihueco Reservoir Irrigators Association & 4.96 & 1.1 & 5.0 \\
\hline & AC Duqueco Cuel Canal & 7.97 & 1.4 & 6.0 \\
\hline & AC Quillón Canal & 2.29 & 1.0 & 2.5 \\
\hline
\end{tabular}

JV: River Administration Board; AC: Irrigation Canal Association; RM: Metropolitan Region; LBO: Libertador General Bernardo O’Higgins Region; acc: Water right allocated proportional to the river or canal discharge; Mha: Thousands of hectares.

River JV which distributes the resource to five ACs in the Maule Region, covering an area under irrigation of 180 636 ha, while the largest AC (the North Maule Canal) covers 70000 ha under irrigation.

The 24 WUAs analyzed present various legal situations (owners of the waterway or in the process of receiving control of the canal from the State, without legal status, etc.) and diversity in terms of their organizational management. As well, there is great variability in terms of the number of water right allotments and flow discharge, surface area under irrigation that they manage, geographic location and presence of technical personnel in charge of administration. This becomes into a broad range of levels of development of capacities (NDC).

All these organizations have an administrative system and defined operational structure that coincides with its statutes, established standards and the rights and duties of the users, with a clear identification and register of its members that is periodically updated and includes, among other things, the name, identification number, address and number of allotment holders. About $75 \%$ of the WUAs file copies of the registration of Water Use Rights in their respective Land Registry Office.

Among the WUAs analyzed there are different systems of water use rights: consumptive, permanent, and eventual rights. All of the WUAs prepare an annual budget, in which the board of directors and users participate actively in the decision making. In $100 \%$ of the WUAs the board of directors is elected, with an annual change of an average of $48 \%$ of the members. Likewise, there are annual work plans in which decisions are taken about improving infrastructure and which encourage the participation and attendance at meetings of the users. As well, in the case that the organizations have professional staff in charge of administration, training programs are carried out for members of the board of directors and for the technical and administrative teams. Finally, the NDC of the WUAs is in the range of Basic to Integrated, and 
those organizations with mayor NDC in most cases have an internal accounting system, conduct administration in their own offices, have means of transport and have lower percentages of unpaid user fees, with values that fluctuate between 0 and $20 \%$ (Figure 1). These values are comparable to the $20 \%$ reported by Molle et al. (2008) in the Jordan Valley irrigation system, the 15\% in WUAs from the coastal region of Peru (Huamanchumo et al., 2008) and the 14\% in WUAs in Turkey (Özlü et al., 2000 cited by Çakmak et al., 2004). On the other hand, the WUAs with lower NDCs have rates of unpaid user fees of up to $55 \%$.

\section{Price paid by the user (PPU)}

In general, the ACs charge users higher prices than JVs, which is explained by the fact that JVs perform more restricted functions than ACs, limiting themselves to delivering a supply of water to the irrigation intakes of the canals under their jurisdiction. Figure 2 shows the broad variability of the PPU, oscillating between $\$ 2665$ (US\$4.9) and \$18 706 (US\$34.5) per hectare irrigated in the season, when the AC administers less than 10000 ha. For larger surface areas, a tendency in the ACs is observed to values between $\$ 1648$ (US\$3.0) and $\$ 7286$ (US\$13.5) per hectare irrigated in the season. For the JVs, the PPU oscillates mainly between $\$ 240$ (US\$0.4) and \$3950 (US\$12.8) per hectare-season (the value of \$240 is not shown in Figure 2, and correspond to a WUA that administers 180600 ha, which is outside the range of the graph). The exception is a JV from the Coquimbo Region, with a PPU of $\$ 9287$ (US\$17.1) per hectare, which administers a complex system of 23500 ha and includes two water reservoirs with a total capacity on the order of 240 million $\mathrm{m}^{3}$. As well, this organization is developing a series of projects related to integrated water management and catchment, as well as education in rural schools of the province.

The PPU values obtained in this study are comparable to the price range for irrigation water per hectare, per year or season in Brazil (US\$3.5), Australia (US\$0.75 to 2.3), New Zealand (US\$6.8 to 16.6) and less than those from Mexico (US\$33 to 60), Italy (US\$21 to 78), Spain (US\$96 to 164.5), Greece (US\$92 to 210) (Dinar, 2000 cited by Çakmak et al., 2004).

\section{Professionalization of WUAs}

Some $62.5 \%$ of the WUAs surveyed (15) have permanent administrative staff, while $37.5 \%$ (9) do not. Nevertheless, $91.7 \%$ (22) uses the services of an accountant, whether as permanent or on contract and $54.2 \%$ (13) have contracted and regularly draw upon professional legal services. In relation to staff for technical support (agronomists and engineers), 62.5\% of the WUAs (15) have permanent staff, 20.8\% (5) contract technical support staff in the irrigation season or for specific consultations, and the rest $16.7 \%$ (4) do not have this type of support. As well, $20.8 \%$ (5) has managerial-administrative and technical-legal support that has allowed them to form parallel companies (consulting, administration or construction), responsible for managing and carrying out investment projects in the irrigation system.

Figure 3 offers a way to visualize the relationship between the degree of professionalization of the WUAs and the extra incomes obtained, where the benefits of having professional staff time are appreciable. It follows that the WUAs that contract more than 25 professional hours per week for administrative management or that are directed by an administrator who also exercises technical functions, have obtained resources that fluctuate between MM\$234 to MM\$2823. For this analysis, 22 WUAs were considered because two ACs are in the process of transferring the intake, conduction and distribution structures from the State to the users, which limits them from applying to public funding instruments.

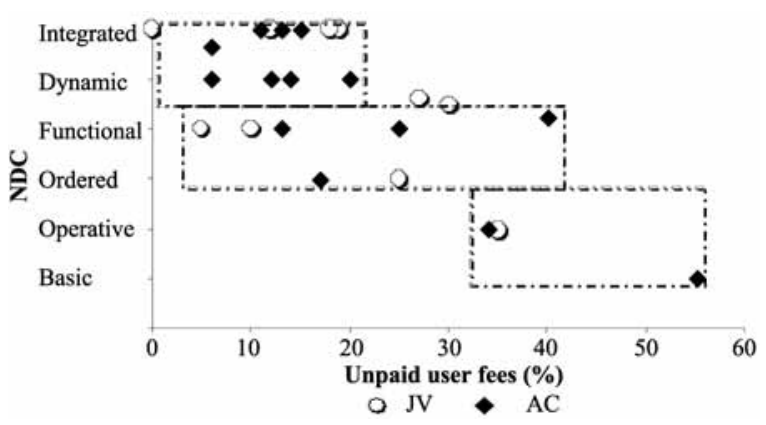

Figure 1. Relationship between the level of capacity development (NDC) and unpaid user fees in 10 River Administration Boards (JV) and 14 Irrigation Canal Associations (AC).

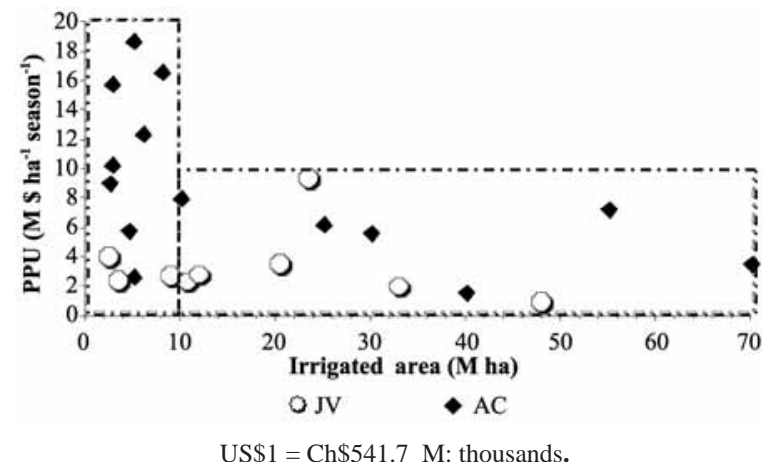

Figure 2. Price paid by users (PPU) depending on irrigated area administrated by nine River Administration Boards (JV) and 14 Irrigation Canal Associations (AC). 
The percentage that the contracting of professional-administrative support of the total amount collected (MTR) by the WUAs is relatively low (Table 3). In the JVs that manage areas under irrigation greater than 30000 ha, the cost of professional services does not exceed $16 \%$, representing values of $\$ 80$ to $\$ 250 \mathrm{ha}^{-1}$ season $^{-1}$. Nevertheless, in the JVs that irrigate from 10000 to 30000 ha, such costs constitute only 8\%, equivalent to $\$ 165$ to $\$ 309$ ha $^{-1}$ season $^{-1}$ (San Martín, 2007).

The ACs that manage areas under irrigation larger than 30000 ha, salaries of core staff represent $7 \%$ of the MTR in a season (Table 4), representing \$400 to \$480 ha $^{-1}$ season $^{-1}$, and in the ACs that irrigate from 10000 to 30000 ha and from 2500 to 10000 ha it represents $6 \%$ and $15 \%$, respectively, which implies values in the range from $\$ 400$ to $\$ 2025$ ha $^{-1}$ season $^{-1}$ (San Martín, 2007).

\section{Analysis of the interviews with members of Boards of Directors}

In 19 of the 24 WUAs to which the interviews were applied $50 \%$ of the members of the board of directors are between 40 and 60 years of age and $43 \%$ are over 60 . About $96 \%$ of the members of the board of directors are male. The term of office of the board members, whether in positions as president, secretary or director, is not related to the NDC. While many WUAs establish regulations that stipulate the annual renewal of the board of directors or part of it, the fact that this change is not complied with does not mean that a WUA lacks an effective system of administration. Additionally, $52 \%$ of the WUAs that responded to the interviews do not have an annual change of the board of directors or part of it. Some larger and successful organizations prefer to conserve their directors because of the good management work they carry out. Nevertheless, other WUAs in the same category conserve part of the board of directors and carry out a partial change in accordance with the established by-law.

The directors of all WUAs with areas under irrigation larger than 10000 ha, have some type of participation in other organizations, whether of a social or productive nature, exercising some position or participating as a member. Some of these organizations are other WUAs, fruit companies, producers' organizations or others. The smaller organizations also relate to other organizations, notably among them other WUAs, agricultural associations and neighborhood associations. It can be

Table 3. Percentage use distribution by items of the total amount collected (MTR) in 10 River Administration Boards, by range of surface area.

\begin{tabular}{|c|c|c|c|}
\hline \multirow[b]{2}{*}{ Item } & \multicolumn{3}{|c|}{ Average of the MTR by range of surface area (ha) } \\
\hline & $2500-10000$ & $10000-30000$ & 30000 and more \\
\hline & & $\%$ & \\
\hline Professional-administrator fees & - & 8 & 16 \\
\hline Core staff salaries & 39 & 33 & 15 \\
\hline General expenses & 24 & 24 & 7 \\
\hline $\begin{array}{l}\text { Others (investment, operational maintenance and transport, } \\
\text { machinery rental and consulting, travel, etc.) }\end{array}$ & 37 & 34 & 62 \\
\hline Total & 100 & 100 & 100 \\
\hline
\end{tabular}

Table 4. Percentage use distribution by items of the total amount collected (MTR) in 14 Irrigation Canal Associations, by range of surface area.

\begin{tabular}{lcrr}
\hline & \multicolumn{3}{c}{ Average of the MTR by range of surface area (ha) } \\
\cline { 2 - 4 } Item & $\mathbf{2 5 0 0 - 1 0 ~ 0 0 0}$ & $\mathbf{1 0 ~ 0 0 0 - 3 0 ~ 0 0 0}$ & $\mathbf{3 0 ~ 0 0 0}$ and more \\
\hline & 15 & 6 & 7 \\
Professional-administrator fees & 29 & 25 & 39 \\
Contracts and wages (cleaning) & 19 & 32 & 37 \\
Core staff salaries & 8 & 6 & 5 \\
General expenses & 29 & 31 & 13 \\
Others (investment, operational maintenance and transport, & & & 100 \\
$\quad$ machinery rental and consulting, travel, etc.) & 100 & 100 & \\
Total & & & \\
\hline
\end{tabular}


deduced that in the larger organizations, the directors or users have a higher level of participation in other types of organizations, whether productive or social. Nevertheless, this indicator does not necessarily represent a better quality of management of the WUA by the directors.

The results of this study indicate that higher levels of formal education of the members of the board of directors can favor the development of the organization (Figure 4), because of which this criterion can be used as a component of the NDC of the WUAs. On the other hand, no relationship was found between the NDC and SBR administered by the WUA, nor with the renewal of the board of directors, nor with the number of water right allotments that the members of the board have.

The WUAs that have contracted professional hours show a minimum value of "Ordered" in their NDC, but when there are no professional hours contracted, the WUAs show a maximum value of "Operative" in their NDC (Figure 5). This has validity discarding an AC with zero professional hours and a "Functional" NDC, given that it received professional support for three years as part of a program for strengthening WUAs (Ministry of Agriculture-National Irrigation Commission, 2006).

\section{Relationship between the PPU and gross margin of production}

The factors that have more influence on direct production costs are inputs like fertilizers, pesticides, labor, harvesting and machinery use (Fundación Chile, 2007). By relating the value that users pay to the WUAs to the average total production cost of the main crops of the zones under study, it can be concluded that this value (PPU) represents less than $4 \%$ of the total production cost of these crops (Table 5). This value is significantly less if it is compared to the $12 \%$ average that represents the irrigation costs in two areas in India, which are derived from the information shown by Kumar et al. (2008)

There was no evidence of any kind of a correlation between the price paid by users (PPU) and the average gross margin (Figure 6), independent of the type of WUA or its geographic location.

\section{CONCLUSIONS}

During the 2005-2006 irrigation season, the price paid by users oscillated between $\$ 2700$ (US $\$ 5.0$ ) and $\$ 18700$ (US\$34.5) ha ${ }^{-1}$ season $^{-1}$, with considerable variability for areas of less than 10000 ha, and values between $\$ 1700$ (US\$3.1) and \$7300 (US\$13.5) ha ${ }^{-1}$ season $^{-1}$ for larger areas. In the JVs, the price paid by users varied between $\$ 240$ (US $\$ 0.4$ ) and $\$ 9300$ (US $\$ 17.2$ ) ha ${ }^{-1}$ season $^{-1}$, without relating them to the area under irrigation that the WUA administers.

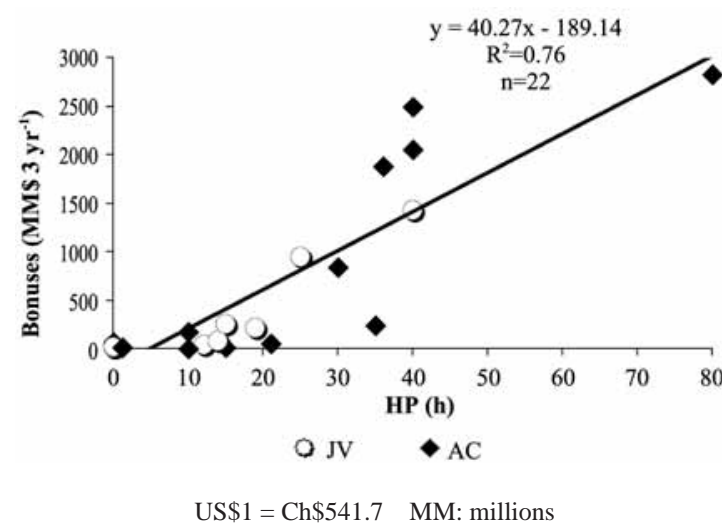

Figure 3. Extra income obtained as bonuses between 2003 and 2005 and weekly professional time (HP) hired in 10 River Administration Boards (JV) and 14 Irrigation Canal Associations (AC) (four JVs and one ACs are in the origin).

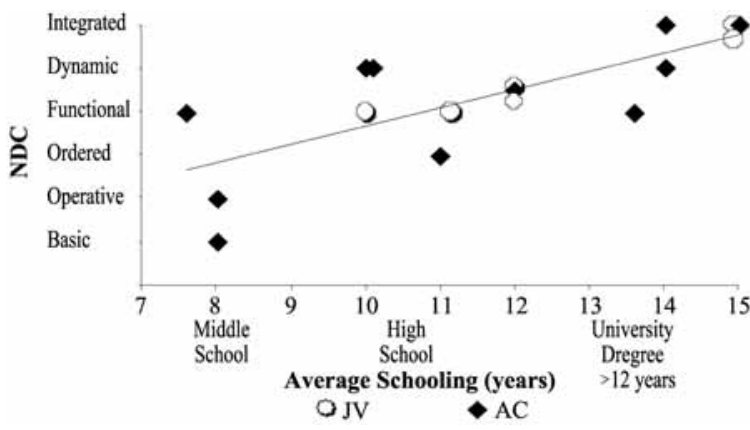

Figure 4. Relationship between Level of Capacity Development (NDC) and average schooling of the council members in seven River Administration Boards (JV) and 12 Irrigation Canal Associations (AC) surveyed.

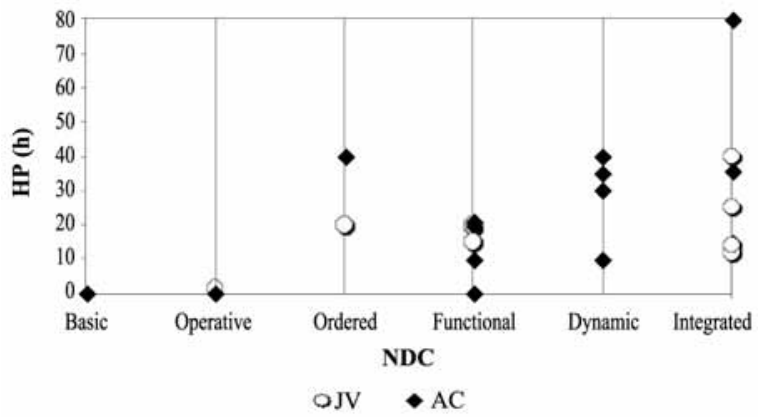

Figure 5. Weekly professional time and Level of Capacity Development (NDC) in 10 RiverAdministration Boards (JV) and 14 Irrigation Canal Associations (AC). 
Table 5. Percentage representation of the value paid by the users (PPU) of River Administration Boards (JV) and Irrigation Canal Association (AC) in the total production cost for the main crops in the irrigated areas under their jurisdiction.

\begin{tabular}{|c|c|c|c|c|c|c|c|c|c|c|c|c|c|c|c|c|}
\hline \multirow[b]{2}{*}{ Region } & \multirow[b]{2}{*}{ Water user organization } & \multicolumn{15}{|c|}{ Representation PPU (\%) } \\
\hline & & $\frac{\vec{E}}{3}$ & 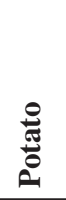 & ڤัٌ & : & है & 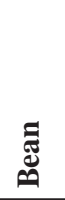 & 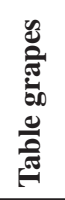 & 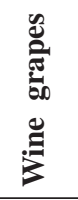 & 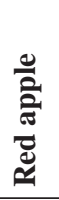 & 产 & 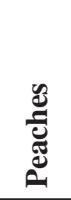 & 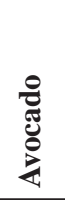 & 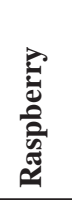 & $\frac{\vec{E}}{3}$ & 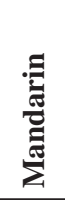 \\
\hline \multirow{6}{*}{ 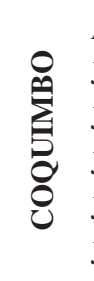 } & AC Punitaqui Canal & & & & & & & 1.0 & & & & & 1.5 & & 1.0 & \\
\hline & JV Illapel River & & & & & & & & & & 0.2 & 0.2 & 0.2 & & 0.2 & \\
\hline & JV Combarbalá River & & & & & & & 0.2 & & & 0.3 & & 0.4 & & 0.4 & \\
\hline & JV Choapa River & & & & & & & & & & 0.2 & 0.2 & 0.2 & & 0.2 & \\
\hline & JV Limarí and Grande Rivers and streams & & & & & & & 0.2 & & & 0.3 & & 0.3 & & & 0.3 \\
\hline & JV Elqui River & & & & & & & 0.5 & & & 1.0 & & 1.0 & & & 0.9 \\
\hline $\mathbf{R M} \mathrm{A}$ & AC del Maipo & 1.5 & 0.6 & & & 0.9 & & 0.3 & & & 0.5 & 0.5 & 0.6 & & 0.5 & \\
\hline \multirow{3}{*}{ 욤 } & JV Cachapoal River $1^{\text {a }}$ Section & 1.0 & & & & 0.6 & 0.7 & 0.2 & 0.5 & 0.2 & & & & & & \\
\hline & AC San Pedro Población y Derivados Canal & 3.5 & & & & 2.6 & 3.3 & 1.0 & 2.4 & 0.8 & & & & & & \\
\hline & AC Cachapoal Canal & 4.0 & & & & 3.1 & 3.8 & 1.5 & 2.8 & 1.0 & & & & & & \\
\hline \multirow{6}{*}{ 孚 } & JV Achibueno River & 0.6 & 0.3 & 0.1 & 0.7 & 0.5 & 0.6 & & & 0.2 & & & & 0.1 & & \\
\hline & AC Putagán Canal & 1.3 & 0.7 & 0.3 & 1.5 & 1.0 & 1.2 & & & 0.3 & & & & 0.3 & & \\
\hline & AC Maule Canal & 0.8 & 0.4 & 0.2 & 0.9 & 0.6 & 0.8 & & & 0.2 & & & & 0.2 & & \\
\hline & AC Maule Sur & 1.4 & 0.7 & 0.3 & 1.5 & 1.0 & 1.3 & & & 0.3 & & & & 0.3 & & \\
\hline & JV Ancoa River and streams & 0.6 & 0.3 & 0.1 & 0.6 & 0.4 & 0.6 & & & 0.1 & & & & 0.1 & & \\
\hline & JV Maule River & 0.1 & 0.0 & 0.0 & 0.1 & 0.0 & 0.1 & & & 0.0 & & & & 0.0 & & \\
\hline \multirow{8}{*}{$\begin{array}{l}\stackrel{0}{\oplus} \\
\stackrel{0}{0} \\
\stackrel{0}{n}\end{array}$} & AC del Laja & 2.0 & 0.8 & 0.3 & & 1.2 & 1.5 & & & & & & & & & \\
\hline & AC Zañartu Canal & 0.5 & 0.2 & 0.1 & & & 0.4 & & & & & & & & & \\
\hline & JV Diguillín River and streams & 0.5 & 0.2 & 0.1 & & & 0.5 & & & & & & & & & \\
\hline & AC Bío-Bío Norte Canal & 1.8 & 0.9 & 0.4 & & & 1.7 & & & & & & & & & \\
\hline & AC Bío-Bío Negrete Canal & 3.8 & 1.9 & 0.8 & & 2.7 & 3.5 & & & & & & & & & \\
\hline & $\begin{array}{l}\text { Asociación de Regantes del Embalse Coihueco } \\
\text { Reservoir Irrigators Association }\end{array}$ & 0.6 & 0.3 & 0.1 & & & 0.6 & & & & & & & & & \\
\hline & AC Duqueco Cuel Canal & 2.8 & 1.4 & 0.6 & & 2.0 & 2.6 & & & & & & & & & \\
\hline & AC Quillón Canal & 2.0 & 1.0 & 0.4 & & & 1.9 & & & & & & & & & \\
\hline
\end{tabular}

Source: Own elaboration. RM: Metropolitan Region. LBO: Libertador General Bernardo O’Higgins Region.

The evaluation of WUAs involved in the study indicates that the administrative management systems differ among organizations of the same type and among the regions under study. Management capacity, measured in terms of the NDC, can be correlated with the average level of schooling of the directors of the WUAs, influencing the percentage of unpaid user fees, in the degree of professionalism or professional hours contracted and the extra incomes that are earned in the WUA. It is observed that the hiring of technical-professional staff in charge of administrative, operational and managerial tasks directly influences the development and growth of the WUA, and provides the tools and vision necessary to obtain extra incomes. The hiring of a professionaladministrator represents between $6 \%$ and $16 \%$ of the total amount collected by the organization, with lower values in WUAs that manage an area under irrigation of 10000 to 30000 ha.

The price paid to WUAs by users represent less than $4 \%$ of the total average cost of production of the main crops in the respective territories and are not related to the incomes generated by the producers or the geographic location of the WUA. 


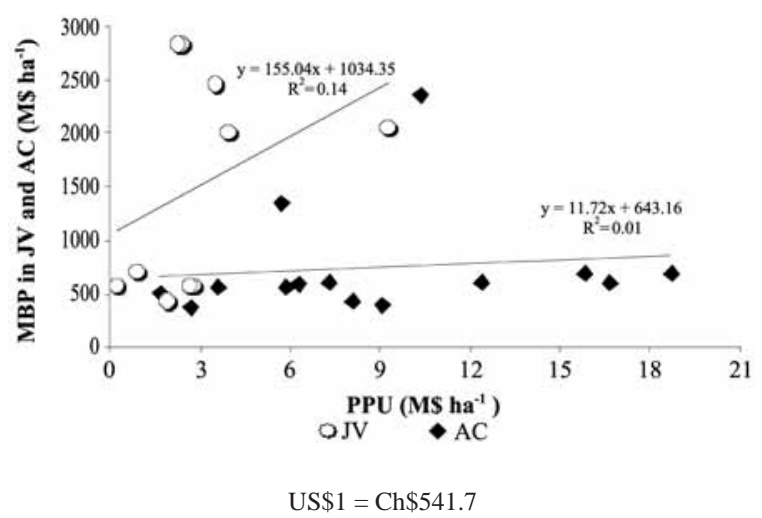

Figure 6. Average gross income margin (MBP) of the area under irrigation in 10 River Administration Boards (JV) and 14 Irrigation Canal Associations and price paid by the users (PPU) for each irrigated hectare.

\section{ACKNOWLEDGEMENTS}

The authors are grateful to the Research Directory of the Universidad de Concepción (DIUC Project $\mathrm{N}^{\circ}$ 208.133.011-1.0), for its funding support to this research. As well, we are grateful for the collaboration of the directors and staff of the River Administration Boards and Irrigation Canal Associations who made this study possible.

\section{RESUMEN}

Administración y gestión del agua de riego en 24 organizaciones de usuarios en Chile. Aproximadamente, el 85\% del agua consumida en Chile es destinada al riego agrícola, siendo administrada por los propios usuarios. En este estudio, se analizó el costo que cancelan los usuarios del agua de riego a sus Organizaciones de Usuarios de Agua (WUAs) y el nivel de profesionalización y desempeño de éstas. Se estudiaron 24 WUAs: 10 Juntas de Vigilancia (JV) y 14 Asociaciones de Canalistas (AC). Se comparó el presupuesto anual de operaciones de cada WUA, el valor que cancelan los usuarios y las capacidades de gestión de la directiva con el desempeño de la respectiva WUA. Además, se analizó la significancia del pago de los usuarios en los costos de producción de los principales cultivos en cada zona. En las AC, la variabilidad de precios por hectárea regada que cancelan los usuarios, disminuye cuando el territorio de la WUA es mayor a 10000 ha, situación no detectada en las JV. El personal técnico-profesional de apoyo incide directamente sobre el desarrollo y crecimiento de las WUAs. Asimismo, las WUAs con nivel de desarrollo de capacidades (NDC) más elevado poseen directivas con mayor escolaridad promedio y los usuarios presentan menor morosidad en el pago. El precio que cancelan los usuarios a las WUAs por hectárea regada representa menos del 4,0\% de los costos promedio totales de producción de los principales cultivos de cada zona. Finalmente, no se evidenció correlación entre el precio que cancelan los usuarios y la rentabilidad promedio de los cultivos, ni por ubicación geográfica de las WUAs.

Palabras clave: costo del agua, organizaciones de usuarios del agua, asociaciones de canalistas, juntas de vigilancia.

\section{LITERATURE CITED}

Banco Central de Chile. 2008. Precio del dólar. Available at http://si2.bcentral.cl/Basededatoseconomicos/951_ 455.asp? $\mathrm{f}=\mathrm{D} \& \mathrm{~s}=\mathrm{UF} \&$ LlamadaPortada $=\mathrm{SI}$ (Accessed 01 April 2008).

Çakmak, B., M. Beyribey, and S. Kodal. 2004. Irrigation water pricing in water user associations. Water Resour. Develop. 20(1):113-124.

De Miguel, L. 2005. Caracterización de las comunidades de agua. Chile Riego 23:29-30.

Fundación Chile. 2007. Programa gestión agropecuaria. Sistemas de producción. Parámetros productivos y de eficiencia. Available at http://www.fundacionchile.cl/ pls/portal/docs/PAGE/PORTAL_CORPORATIVO/ ADMINISTRACION_DEL_CONTENIDO/ AGROINDUSTRIA_FUNDACION_CHILE/HTML/ Agrogestion_Fichas_1.html\#proyecto (Accessed 13 November 2008).

Galaz, V. 2004. Stealing from the poor? Game theory and the politics of water markets in Chile. Environ. Politics 13(2):414-437.

Garduño, H. 2003. Administración de derechos de agua. Experiencias, asuntos relevantes y lineamientos. FAO Estudio Jurídico $\mathrm{N}^{\circ}$ 81. 38 p. FAO, Roma, Italia.

Garrido, A., E. Palacios, J. Calatrava, A. Exebio, J. Chavez, y E. Mejía. 2007. La importancia del valor, costo y precio de los recursos hídricos en su gestión. 87 p. Colegio de Posgraduados de México, México.

Herrera P., G. van Huylenbroeck, R. Espinel, e I. Vanslembrouck. 2004. Valoración económica y economía institucional del agua de riego en la península de Santa Elena-Ecuador. Revista Tecnológica 17(1): 219-229. Available at http://www.rte.espol.edu.ec/ archivos/Revista_2004/27\%20VALORACION\%20E CONOMICA\%20Y\%20ECONOMIA.pdf (Accessed May 2007).

Huamanchumo, J., Y. Peña, L. Silva, and J. Hendriks. 2008. Developing capacity in water users organizations: The case of Peru. Irrig. Drain. 57:300-310. 
Jouravlev, A. 2001. Administración del agua en América Latina y el Caribe en el umbral del siglo XXI. Serie Recursos Naturales e Infraestructura $\mathrm{N}^{\circ} 27.77$ p. CEPAL, Santiago, Chile.

Kumar, M.D., A.K. Malla, and S.K. Tripathy. 2008. Economic value of water in agriculture: Comparative analysis of a water-scarce and water-rich region in India. Water International 33(2):214-230.

Larrañaga, P., L. Yánez, A. Peña, y R. Villa. 2003. Catastro frutícola. Principales resultados VI Región. 50 p. ODEPA-CIREN, Santiago, Chile.

Larrañaga, P., L. Yánez, A. Peña, y R. Villa. 2005. Catastro frutícola. Principales resultados IV Región. 42 p. ODEPA-CIREN, Santiago, Chile.

Larrañaga, P., L. Yánez, y R. Villa. 2004. Catastro frutícola. Principales resultados Región Metropolitana. 50 p. ODEPA-CIREN, Santiago, Chile.

Larrañaga, P., A. Peña, y R. Villa. 2006. Catastro frutícola. Principales resultados VIII Región. 42 p. ODEPACIREN, Santiago, Chile.

Melo, O., G. Carozzi, J. Jara, J. Vial, L. Moreno, y A. Ibarra. 2005. Las comunidades de agua en Chile. Una visión desarrollada a partir del diagnóstico de dichas organizaciones. Universidad de Concepción, Facultad de Ingeniería Agrícola. Documento presentado en el XX Congreso Nacional del Agua y III Simposio de Recursos Hídricos del Cono Sur. Departamento General de Irrigación y Comité Permanente de los Congresos Nacionales de Agua, Mendoza, Argentina.
Ministerio de Agricultura-Comisión Nacional de Riego. 2006. Programa de organización y capacitación de organizaciones de usuarios del agua y desarrollo de organizaciones territoriales para diversas regiones del país. Resumen Ejecutivo - Informe final. Available at http://www.chileriego.cl/opensite/frm_opensite. asp?glb_cod_sistema $=20020129172812 \&$ glb_cod_ nodo=20041125172511\&glb_cod_nodo_recarga=20 070820170335\&glb_send=link (Accessed December 2007).

Ministerio de Obras Públicas - Dirección General de Aguas. 1999. Política nacional de recursos hídricos. 58 p. Ministerio de Obras Públicas, Dirección General de Aguas, Santiago, Chile.

Molle, F., J-P. Venot, and Y. Hassan. 2008. Irrigation in the Jordan Valley: Are water pricing policies overly optimistic? Agr. Water Manage. 95:427-438.

República de Chile. 2006. Código de aguas. 286 p. Editorial Jurídica de Chile. Edición Oficial aprobada por Decreto 1442 del 29 de diciembre del 2006 del Ministerio de Justicia, Santiago, Chile.

San Martín, A. 2007. Evaluación del costo de administración y gestión del agua en algunas organizaciones de usuarios en Chile. 103 p. Tesis Ingeniero Civil Agrícola. Universidad de Concepción, Facultad de Ingeniería Agrícola, Chillán, Chile. 